\title{
Plant Growth Retardants Improve Sink Strength and Yield of Sunflower
}

\author{
A.S. Pious Secondo and Y.A. Nanja Reddy* \\ Department of Crop Physiology, University of Agricultural Sciences, GKVK, \\ Bengaluru - 560065, Karnataka, India \\ *Corresponding author
}

\begin{tabular}{|l|}
\hline Ke y w o r d s \\
$\begin{array}{l}\text { Sunflower, Paclobutrazol, } \\
\text { Cycocel, Mepiquat } \\
\text { chloride, Plant height, } \\
\text { Sink strength, Seed yield }\end{array}$ \\
\hline Article Info \\
\hline $\begin{array}{l}\text { Accepted: } \\
\text { 04 September } 2018 \\
\text { Available Online: } \\
\text { 10 October } 2018\end{array}$ \\
\hline
\end{tabular}

A B S T R A C T

KBSH-44, a public sector sunflower hybrid has high biomass production capacity with yield comparable to other popular hybrids. This hybrid is tall with more stalk weight wherein, photo-assimilates are locked up in vegetative parts with a reduced translocation to their productive structures (seed). Any approach, which reduces the plant height, may improve the translocation efficiency to the seed and thus seed yield. In this context, a field experiment was conducted to reduce the plant height by foliar application of plant growth retardants viz., paclobutrazol (PBZ), mepiquat chloride (MPC) and chloromequat chloride (CCC) to improve the sink strength. Application of growth retardants at 39 days after sowing reduced the plant height immediately after the application. However, the plant height recovered by the time of crop maturity. Application of mepiquat chloride twice (39and 52 days after sowing) resulted in increased seed yield (49.8 $\left.\mathrm{g} \mathrm{plant}^{-1}\right)$ over the control (35.2 $\left.\mathrm{g} \mathrm{plant}^{-1}\right)$ and even over the cycocel or paclobutrazol treatment. The increased seed yield $(41.5 \%)$ with mepiquat chloride was due to increased sink strength parameters such as increased seed number (820 seeds per thalamus), test weight (6.01 g 100 seeds) and HI (0.35) over unsprayed control plants.

\section{Introduction}

Sunflower has gained popularity worldwide because of its premium oil, recognized for its high polyunsaturated fatty acid content with no cholesterol compared to other vegetable oils (Francois, 1996). Present world consumption of oils is 123.8 million tons and expected to increase to 137 million tons per year in the next decade (ISTA, 2016). Sunflower is the third largest source of vegetable oil worldwide next to soybean and groundnut both in terms of area and production (Yeremenko et al., 2017). In terms of production, the top countries are Ukraine (11.9 million tons), Russia (9.7 mt), European Union (7.72 $\mathrm{m} \mathrm{t})$, Argentina (2.7 $\mathrm{m} \mathrm{t})$, Turkey $(1.1 \mathrm{~m} \mathrm{t})$, India $(0.52 \mathrm{~m} \mathrm{t})$ and others (7.18 million tons) (FAOSTAT, 2017). The global sunflower area is 25.2 million hectares and in India, cultivated in an area of 0.82 million hectares with a production of 0.52 million tons and productivity of $707 \mathrm{~kg} \mathrm{ha}^{-1}$ (FAOSTAT, 2014). The production of sunflower in India is concentrated in Karnataka, Andhra Pradesh, Maharashtra and Tamil Nadu. Karnataka is the leading state in terms of area and production accounting for 0.42 million hectares and 0.25 
million tons with a productivity of $693 \mathrm{~kg}$ per ha $^{-1}$ (FAOSTAT, 2014).

The major physiological constraints in sunflower production are excessive vegetative growth, lack of photosynthetic activity during the time of seed filling, poor translocation of photosynthates and poor seed set in the cultivated hybrids (Patil and Dhomne, 1997). In this direction, the sunflower hybrid, KBSH44 (a public sector hybrid) has high biomass production potential with tall nature of plant and yield comparable to other popularly cultivated hybrids. It is hypothesized that, in this hybrid, a greater proportion of photosynthates are diverted for production and maintenance of vegetative plant parts rather than translocation to reproductive parts and hence, the plant puts on more plant height and higher biomass. Therefore, any attempts to reduce plant height would be expected to improve the seed yield by diverting the photosynthates to reproductive structures which otherwise goes for vegetative growth. In an earlier study, possibility to enhance the seed yield of sunflower by diverting large quantity of biomass locked up in vegetative parts towards seed filling has been reported (Nanja Reddy et al., 2003). Several studies showed that, the plant growth retardants such as paclobutrazol, cycocel, mepiquat chloride and ethephonare capable of reducing plant height and thus increased translocation of photo-assimilates to reproductive structures (seed) in sunflower (Kashid et al., 2010; Spitzer et al., 2011; Polat et al., 2017). Keeping this in view, the field experiment was conducted to investigate the influence of plant growth retardants on plant height and its consequent effect on sink strength and yield of sunflower hybrid, KBSH-44.

\section{Materials and Methods}

Field experiments were conducted during kharif season 2017 and summer, 2018at All India Coordinated Research Project on sunflower, Zonal Agricultural Research Station, University of Agricultural Sciences, Bengaluru, Karnataka, India situated at $30^{\circ}$ North latitude and $77^{\circ} 35$ East longitudes with an altitude of 930 meter above mean sea level. The soil is red sandy loam nearly at neutral $\mathrm{pH}$ (6.7) and with normal electrical conductivity $\left(0.22 \mathrm{dSm}^{-1} 25{ }^{\circ} \mathrm{C}\right)$. The available nitrogen $\left(355 \mathrm{~kg} \mathrm{ha}^{-1}\right)$, phosphorus $\left(50.49 \mathrm{~kg} \mathrm{ha}^{-1}\right)$ and potassium content $\left(243 \mathrm{~kg} \mathrm{ha}^{-1}\right)$ in the soil were medium. Recommended dose of 60:90:60 kg N, $\mathrm{P}_{2} \mathrm{O}_{5}, \mathrm{~K}_{2} \mathrm{O}$ per hectare in the form of Urea, Di Ammonium Phosphate and Muriate of potash was applied to the soil. Full dose of $\mathrm{P}$ and $\mathrm{K}$ and; half of the $\mathrm{N}$ were applied at the time of sowing and the remaining half of the $\mathrm{N}$ was applied at 35 days after sowing. Farm yard manure (FYM) @ 7.5 $\mathrm{t} \mathrm{ha}^{-1}$ was applied 15 days prior to sowing so as to undergo decomposition. Both the experiments were laid out in the randomized complete block design (RCBD). The first experiment consisted of seven treatments with four replications. The treatments were foliar sprays of water, cycocel, paclobutrazol and mepiquat chloride (detailed with data). Regular irrigation and plant protection measures were taken up. Five plants from each replication were selected randomly, various growth and yield parameters were recorded and the data was analyzed using the statistical package, OPSTAT (Sheoran et al., 1998).

Since the higher reduction in plant height was noticed in the first experiment with cycocel, the second experiment was carried out to study the effect of higher concentration (3000 ppm) of chloromequat chloride (cycocel) applied at different growth stages on the plant height in sunflower hybrid, KBSH-44. The experiment consisted eight treatments and three replications. The treatments were control (water spray), application of cycocel at 4 leaves stage, 6 leaves stage, 8 leaves stage, 10 leaves stage, 12 leaves stage, 14 leaves stage and 16 leaves stage. The plant height was measured on 30 and $60^{\text {th }}$ day after sowing. 


\section{Results and Discussion}

\section{Effect of plant growth retardants on growth parameters}

Foliar application of plant growth retardants, cycocel (CCC, $1500 \mathrm{ppm})$ and paclobutrazol (PBZ, 12.5g a.i./ hectare) on $39^{\text {th }}$ DAS (just prior to star bud stage) reduced the plant height significantly by 12 days after the spray. The cycocel was more effective than other growth retardants. However, several days after application of growth retardants, the plant height was recovered to normal height and hence, the plant height did not differ significantly between the treatments at 60 DAS and at harvest (Table 1). In a similar study, Gayithri (2015) reported that, the application of cycocel at $1500 \mathrm{ppm}$ was not effective in reducing the plant height at flowering and at maturity in sunflower hybrid, KBSH-44, however, higher concentration of cycocel $(3000 \mathrm{ppm})$ reduced the plant height significantly. In another study, Koutroubas et al., (2004) reported that, the foliar application of paclobutrazol (@12.5 g a.i/ha) at 33 DAS and 48 DAS decreased the plant height at 10 days after spray. However the mepiquat chloride (@25g a.i/ha) was not effective to reduce the plant height immediately after spray, but has delayed effect, and reduced the plant height by the time of flowering and at maturity. Such reduced plant height with mepiquat chloride by crop maturity decreased the seed yield significantly. Therefore, application of growth retardants at a lower or normal dose reduces the plant height in a few days after application and recovers by the time of crop maturity. Higher concentration of growth retardants reduces the plant height effectively but has negative effect as it reduces the biomass. In contrast, a temporary reduction in plant height will not alter the biomass production, rather it will be useful to increase the sink strength parameters and seed yield. Based on the earlier reports and also as cycocel was more effective in reducing the plant height (first experiment, Table 1), cycocel (1500 and $3000 \mathrm{ppm}$ ) was sprayed at different time intervals to monitor the plant height at 30 and 60 DAS (Table 2). The cycocel (1500 and $3000 \mathrm{ppm}$ at different leaf stages) decreased the plant height soon after the foliar application and tends to recover with time i.e., 30 DAS. The recovery was to a lesser extent at higher concentration of 3000 ppm (Table 2). Therefore, at lower concentration (1500 ppm), plant height was recovered and hence no significant differences by 60 DAS. However, at higher concentration (3000 ppm), the recovery was less and hence remained significant differences in the plant height at 60 DAS. The cycocel @ 3000 ppm was more effective in reducing the plant height irrespective of the stage of application and the effect was long lasting. Such observation of reduced plant height at higher concentration $(3000 \mathrm{ppm})$ of cycocel has also reported by Gayithri (2015). The cycocel being an anti-gibberellin compound it reduces the cell elongation and plant height (Lovett and Orchard, 1974). The results therefore suggest that, the growth retardants at lower concentrations would be useful for a temporary reduction, but increases the partitioning and seed yield.

Foliar application of plant growth retardants did not influence the stem diameter significantly both at 60 DAS and at harvest stage (Table 1). Pathak and Dixit (1994) and Kashid (2008) also noticed no improvement in stem diameter due to foliar application of growth retardants over the control plants.

Number of leaves per plant did not differ significantly due to application of different growth retardants (Table 1). Such observations was also made by Koutroubas et al., (2014) wherein they reported no effect of cycocel, mepiquat chloride and paclobutrazol on number of leaves per plant. 
Table.1 Effect of plant growth retardants on plant height, stem diameter, number of leaves per plant and leaf area index (LAI) in sunflower hybrid, KBSH-44

\begin{tabular}{|c|c|c|c|c|c|c|c|}
\hline \multirow[t]{2}{*}{ Treatment details } & \multicolumn{3}{|c|}{ Plant height (cm) } & \multicolumn{2}{|c|}{ Stem girth $(\mathrm{cm})$} & \multirow{2}{*}{$\begin{array}{c}\begin{array}{c}\text { No. of } \\
\text { leaves/ } \\
\text { plant }\end{array} \\
60 \\
\text { DAS }\end{array}$} & \multirow{2}{*}{$\begin{array}{c}\text { LAI } \\
60 \\
\text { DAS }\end{array}$} \\
\hline & $52 \mathrm{DAS}$ & 60 DAS & Harvest & 60 DAS & Harvest & & \\
\hline $\mathrm{T}_{1}=$ Control (water spray at 39 and $\left.52 \mathrm{DAS}\right)$ & 175.4 & 194.4 & 196.2 & 2.395 & 2.345 & 23.75 & 3.840 \\
\hline$T_{2}=$ Cycocel $(1500 \mathrm{ppm}$ at $39 \mathrm{DAS})$ & 158.8 & 184.1 & 186.4 & 2.355 & 2.285 & 24.75 & 3.608 \\
\hline $\mathrm{T}_{3}=$ Cycocel $(1500 \mathrm{ppm}$ at 39 and $52 \mathrm{DAS})$ & 159.8 & 183.3 & 185.1 & 2.300 & 2.295 & 25.00 & 3.663 \\
\hline $\mathrm{T}_{4}=$ Paclobutrazol $(12.5 \mathrm{~g}$ a.i /ha at $39 \mathrm{DAS})$ & 162.6 & 188.4 & 191.1 & 2.390 & 2.305 & 25.50 & 4.423 \\
\hline $\mathrm{T}_{5}=$ Paclobutrazol (12.5 $\mathrm{g}$ a.i/ha at 39 and $\left.52 \mathrm{DAS}\right)$ & 167.5 & 191.2 & 192.6 & 2.350 & 2.265 & 24.75 & 4.025 \\
\hline $\mathrm{T}_{6}=$ Mepiquat chloride (25.0 $\mathrm{g}$ a.i/ha at $\left.39 \mathrm{DAS}\right)$ & 173.3 & 192.8 & 194.0 & 2.370 & 2.310 & 25.25 & 4.193 \\
\hline $\begin{array}{l}\mathrm{T}_{7}=\text { Mepiquat chloride }(25.0 \mathrm{~g} \text { a.i/ha at } 39 \text { and } 52 \\
\text { DAS })\end{array}$ & 167.0 & 186.1 & 187.5 & 2.355 & 2.285 & 25.25 & 3.995 \\
\hline Mean & 166.3 & 188.6 & 190.4 & 2.359 & 2.299 & 24.89 & 3.964 \\
\hline SEm \pm & 3.2 & 3.6 & 3.4 & 0.052 & 0.040 & 0.49 & 0.159 \\
\hline CD@ $@ 5 \%$ & 9.4 & NS & NS & NS & NS & NS & 0.475 \\
\hline C.V. \% & 3.8 & 3.9 & 3.6 & 4.416 & 3.490 & 3.96 & 8.0 \\
\hline
\end{tabular}

Note: Date of sowing (04-10-2017), $1^{\text {st }}$ spray was given on 12-11-2017 coinciding with 8 leaf stage $\&$ just prior to star bud formation (39 DAS)and $2^{\text {nd }}$ spray was given on 25-11-2017 (52 DAS i.e., nearly 10 days after star bud stage) 
Table.2 Effect of chloromequat chloride (cycocel) spray on plant height in sunflower hybrid, KBSH-44

\begin{tabular}{|c|c|c|c|c|c|}
\hline \multirow[t]{2}{*}{$\begin{array}{c}\text { Treatment } \\
\text { (Leaf stage at which spray was taken) }\end{array}$} & \multirow{2}{*}{$\begin{array}{c}\text { Days } \\
\text { after } \\
\text { sowing }\end{array}$} & \multicolumn{2}{|c|}{$\begin{array}{c}\text { Plant height at } 30 \text { DAS } \\
(\mathrm{cm})\end{array}$} & \multicolumn{2}{|c|}{$\begin{array}{c}\text { Plant height at } 60 \text { DAS } \\
(\mathrm{cm})\end{array}$} \\
\hline & & 1500 ppm & 3000 ppm & 1500 ppm & 3000 ppm \\
\hline 4 (Water) & 13 & 67.00 & 67.00 & 202.89 & 205.89 \\
\hline 4 & 13 & 62.22 & 60.78 & 190.44 & 187.56 \\
\hline 6 & 17 & 58.00 & 55.33 & 180.11 & 179.44 \\
\hline 8 & 21 & 58.22 & 54.33 & 190.78 & 185.11 \\
\hline 10 & 25 & 59.00 & 54.33 & 196.11 & 189.11 \\
\hline 12 & 29 & & & 189.56 & 184.89 \\
\hline 14 & 33 & & & 190.33 & 180.00 \\
\hline 16 & 37 & & & 197.78 & 191.56 \\
\hline Mean & & 60.89 & 58.35 & 188.50 & 187.95 \\
\hline SEm \pm & & 1.22 & 1.32 & 4.95 & 3.33 \\
\hline CD@ $9 \%$ & & 3.50 & 3.77 & NS & 9.47 \\
\hline C.V. (\%) & & 6.05 & 6.87 & 7.72 & 5.32 \\
\hline
\end{tabular}

Note: Date of sowing (28-03-2018), $1^{\text {st }}$ spray was given on 11-04-2018 coinciding with 4 leaf stage and continued subsequently with an interval of four days. 
Table.3 Effect of growth retardants on yield and yield attributes in sunflower hybrid, KBSH-44

\begin{tabular}{|c|c|c|c|c|c|c|c|c|c|}
\hline Treatments & $\begin{array}{c}\text { Leaf } \\
\text { dry } \\
\text { weight } \\
\left(\mathrm{g} \mathrm{pl}^{-1}\right)\end{array}$ & $\begin{array}{c}\text { Stem } \\
\text { dry } \\
\text { weight } \\
\left(\mathrm{g} \mathrm{pl}^{-1}\right)\end{array}$ & $\begin{array}{c}\text { Thala } \\
\text { mus } \\
\text { dry } \\
\text { weight } \\
\left(\mathrm{g} \mathrm{pl}^{-1}\right)\end{array}$ & $\begin{array}{c}\text { Head } \\
\text { diame } \\
\text { ter } \\
(\mathrm{cm})\end{array}$ & $\begin{array}{c}100 \\
\text { seed } \\
\text { weight } \\
(\mathrm{g})\end{array}$ & $\begin{array}{c}\text { No. of } \\
\text { seeds/ } \\
\text { thala } \\
\text { mus }\end{array}$ & $\begin{array}{c}\text { TDM } \\
\left(\mathrm{g} \mathrm{pl}^{-1}\right)\end{array}$ & HI & $\begin{array}{c}\text { Seed } \\
\text { weight } \\
\left(\mathrm{g} \mathrm{pl}^{-1}\right)\end{array}$ \\
\hline $\mathrm{T}_{1}=$ Control (water spray at 39 and 52 DAS) & 28.28 & 41.7 & 15.4 & 13.8 & 5.23 & 673.9 & 120.6 & 0.295 & 35.2 \\
\hline $\mathrm{T}_{2}=$ Cycocel $(1500 \mathrm{ppm}$ at $39 \mathrm{DAS})$ & 30.03 & 40.3 & 15.2 & 13.9 & 5.47 & 715.0 & 124.5 & 0.313 & 39.0 \\
\hline $\mathrm{T}_{3}=$ Cycocel $(1500 \mathrm{ppm}$ at 39 and $52 \mathrm{DAS})$ & 26.30 & 39.3 & 16.0 & 13.5 & 5.66 & 649.0 & 118.2 & 0.310 & 36.7 \\
\hline $\mathrm{T}_{4}=$ Paclobutrazol (12.5 g a.i /ha at $\left.39 \mathrm{DAS}\right)$ & 29.50 & 42.9 & 14.7 & 13.8 & 5.85 & 661.2 & 125.6 & 0.308 & 38.6 \\
\hline $\mathrm{T}_{5}=$ Paclobutrazol (12.5 g a.i/ha at 39 and $\left.52 \mathrm{DAS}\right)$ & 28.45 & 41.9 & 15.8 & 13.9 & 5.57 & 723.3 & 126.4 & 0.323 & 40.2 \\
\hline $\mathrm{T}_{6}=$ Mepiquat chloride (25.0 $\mathrm{g}$ a.i/ha at $\left.39 \mathrm{DAS}\right)$ & 31.83 & 35.5 & 15.5 & 14.0 & 5.67 & 743.1 & 125.0 & 0.348 & 42.1 \\
\hline $\begin{array}{l}\mathrm{T}_{7}=\text { Mepiquat chloride }(25.0 \mathrm{~g} \text { a.i/ha at } 39 \text { and } 52 \\
\text { DAS) }\end{array}$ & 30.95 & 44.5 & 15.8 & 14.2 & 6.01 & 819.9 & 141.0 & 0.350 & 49.8 \\
\hline Mean & 29.33 & 40.9 & 15.5 & 13.9 & 5.64 & 712.3 & 125.9 & 0.321 & 40.2 \\
\hline SEm \pm & 1.52 & 4.02 & 0.53 & 0.27 & 0.09 & 36.5 & 5.89 & 0.02 & 2.57 \\
\hline CD@5\% & NS & NS & NS & NS & 0.28 & NS & NS & NS & 7.69 \\
\hline C.V. \% & 10.37 & 19.7 & 6.89 & 3.9 & 3.34 & 10.2 & 9.35 & 11.0 & 12.8 \\
\hline
\end{tabular}

Note: Date of sowing (04-10-2017), $1^{\text {st }}$ spray was given on 12-11-2017 coinciding with 8 leaf stage \& just prior to star bud formation (39 DAS)and $2^{\text {nd }}$ spray was given on 25-11-2017 (52 DAS i.e., nearly 10 days after star bud stage) 
The leaf area index (LAI) did not decrease significantly over the control, instead the LAI was increased with paclobutrazol and mepiquat chloride. Similar to our results, Gayithri (2015) also reported higher LAD (132.7 days) with paclobutrazol at $12.5 \mathrm{~g} \mathrm{ha}^{-1}$ and a minimum LAD (108.3 days) in cycocel (1500 ppm). The maintenance of higher LAI may be due to delayed leaf senescence, prevention of chlorophyll degradation and protease activity (Kashid, 2008) and such higher LAI would maintain the photosynthetic activity for a longer period with optimum concentration of growth retardants and lead to higher productivity.

\section{Effect of plant growth retardants on yield parameters}

Crop yield is the result of assimilates synthesized during the growing period and its allocation to the reproductive structures (source-sink relationship). The total dry matter is an important component of the seed yield and the components of dry matter viz., weight of leaf, stem and thalamus at the time of crop harvest did not differ significantly between the treatments. However, these parameters were higher by $16.9 \%, 9.4 \%$, $6.7 \%$ and $2.6 \%$ respectively when mepiquat chloride was applied at 39 and 52 DAS (Table 3 ), suggests that, the growth retardants at an optimum concentration do not affect the biomass production and hence any improvement sink parameters without affecting the total biomass would enhance the seed yield of sunflower significantly.

Higher diameter of thalamus would be required to accommodate higher seed number and seed yield. No significant differences between the treatments were observed for thalamus size (Table 3). Similar to our results, no improvement in head diameter was obsrerved with normal concentration of growth retardants and whereas, higher concentration reduced the thalamus size (Koutroubas et al., 2014; Gayithri, 2015 and Polat et al., 2017). Further, increase in diameter may lead to increased storage of carbohydrates in the thalamus rather than translocation to seed. Therefore, without any increase in head diamter, accommodating the higher seed number with no central sterility would a better option for higher yields.

The major sink strength parameters viz., the test weight and seed number are the important determinants for achieving the higher seed yield. Application of MPC (@25 ga.i. ha ${ }^{-1}$ ) at 39 and 52 DAS increased the test weight by $14.9 \%$ and seed number by $21.7 \%$ as compared to the control (Table 3). Our results are in conformity with the findings of Kashid et al., (2010) and Sable et al., (2015), suggesting that the growth retardants at an appropriate dosage and time improves the sink strength.

The seed yield was higher in all the growth retardant treatments as compared to the control and it was significantly superior when the mepiquat chloride was applied 39 and 52 DAS (49.8 $\mathrm{g} \mathrm{plant}^{-1}$ ) as compared to control (35.2 $\left.\mathrm{g} \mathrm{plant}^{-1}\right)$. Thalamus size remaining similar between the treatments, the improved sink strength parameters with the application of mepiquat chloride might have improved central fertility in addition to seed number, test weight, and thus lead to higher seed yield. Similar reports of increased seed yield with mepiquat chloride (300 ppm) has been reported by Anitha et al., (2007), Sawan et al., (2007) and Polat et al., (2017). These results suggest that, the mepiquat chloride could be a better growth retardant as compared to $\mathrm{CCC}$ or paclobutrazol for increasing the seed yield of sunflower.

Exogenous application of plant growth retardants at 39 DAS (nearly at initiation of star bud) at an appropriate concentration 
would reduce the plant height temporarily and recovers with time. However, application of growth retardant, mepiquat chloride (at the rate of $25 \mathrm{~g} \mathrm{ha}^{-1}$ ) at 39 and 52 DAS improves the sink strength (seed number and seed filling) and increases the seed yield of high biomass producing sunflower hybrids, like $\mathrm{KBSH}-44$. It appears that temporary reduction in plant height at star bud stage would help in higher translocation of photosynthates to seed without affecting the total biomass and hence the higher seed yield with growth retardant.

\section{Acknowledgement}

Pious Secondo, would like to thank Dr. T.K. Nagarathna, Registrar, PPV\&FRA, New Delhi, Dr. N. NatarajaKaraba, Professor, Department of Crop Physiology, Dr. A. Sathish, Associate Professor, Department of Agril. Chemistry and Soil Science, Dr. P. Boraiah, Senior Farm Superintendent, UAS, GKVK, Mr. Mujahid Anjum, Mr. H.G. Praveen, Department of Crop Physiology, and Ms. Gayithri, AICRP on sunflower, UAS, Bengaluru for their support to conduct the experiments.

\section{References}

Anitha, R., Sritharan, N., Vanangamudi, M., and Jeyakumar, P., 2007. Effect of certain plant growth regulators on growth and yield of sunflower. Plant. Archieves. 7: 309-312.

FAOSTAT, 2014. http://faostat.fao.org/site/ 636/default.aspx\#ancor.

FAOSTAT, 2017. http://faostat.fao.org/site/ 636/default.aspx\#ancor

FRANCOIS, 1996. Salinity effects on four sunflower hybrids. Agronomy Journal. 88: 2-61.

Gayithri, M., 2015.Influence of source and sink manipulations on growth and productivity in sunflower (Helianthus annuus L.), M.Sc. (Agri.), Department of Crop Physiology, UAS, GKVK, Bengaluru.

ISTA, 2016. Oil world global market research on oilseeds, oils, and meal, Global India, www.oilworld.de

Kashid, D. A., Doddamani, M. B., Chetti, M. B., Hiremath, S. M., and Arvindkumar, B. N., 2010. Effect of growth retardants on morpho-physiological traits and yield of sunflower, Karnataka Journal of Agricultural Sciences. 23(2): 347349.

Kashid, D.A., 2008. Effect of growth retardants on growth, physiology and yield in sunflower, Ph.D. (Agric.) thesis, Univ. Agril. Sci., Dharwad.

Koutroubas, S.D., Papakosta, D.K. and Doitsinis, A., 2004. Cultivar and seasonal effects on the contribution of pre-anthesis assimilates to safflower yield. Field Crops Research. 90: 263274.

Koutroubas, S.D., Vassiliou, G. and Damalas, C.A, 2014. Sunflower morphology as affected by foliar application of plant growth regulators, International Journal of Plant Prod. 8 (2): 215-230.

Lovett, J.V. and Orchard, P.W., 1974, Influence of CCC on sunflower growth, development and yield under controlled environment and field conditions. Proc. $6^{\text {th }}$ Intl. Sunflower Conf., Bucharest, Romania, 22-24 ${ }^{\text {th }}$ July, 1974, 1: 153159.

Nanja Reddy, Y. A., Uma Shaanker, R., Prasad, T. G., and Udaya Kumar, M., 2003. Physiological approaches to improve harvest index and productivity in sunflower. Helia. 26(38): 81-90.

Pathak, H.C. and Dixit, S.K., 1994.Yield and yield contributing characters of sunflower (Helianthus annuus L.) as influenced by cycocel (CCC).Gujarat Agricultural University Research Journal.20 (1): 158-161. 
Patil, B. N. and Dhomne, M. B., 1997. Influence of plant growth retardants on yield and yield contributing characters in sunflower. Journal of Maharashtra Agricultural University.22 (2): 213-214.

Polat, T., Ozer, H., Ozturk, E. and Setaoglu, F., 2017. Effects of mepiquat chloride applications on non-oilseed sunflower, Turkish Journal of Agriculture and Forestry. 41: 472-479.

Sable, P.B., Ransingh, U.R. and Waskar, D.P., 2015, Effect of foliar application of plant growth regulators on growth and flower quality of gladiolus $\mathrm{Cv}$. Journal of Hortcultural Research. 2(3): 100-141.

Sawan, Z.M., Hafez, S.A. and Basyony, A.E., 2007. Effect of nitrogen fertilization and foliar application of plant growth retardants and zinc on cottonseed, protein, and oil yield and oil properties of cotton. Journal of Agronomy and Crop Science. 186(3): 183-191.
Sheoran, O.P., Tonk, D.S., Kaushik, L.S., Hasija, R.C, and Pannu, R.S., 1998. Statistical software package for agricultural research workers. Recent advances in information theory, statistics and computer applications by D.S. Hooda \& R.C. Hasija Department of Mathematics Statistics, CCS HAU, Hisar (139-143).

Spitzer, T., Mutusinsky, P., Klemova, Z. and Kazda, J., 2011. Management of sunflower stand height using growth regulators. Plant Soil and Environment. 57: 357-363.

Yeremenko, O., Kalenska, S., Kiurchev, S., Rud, A., Chynchyk, O. and Semenov, O., 2017. Sunflower (Helianthus annuиs L.) productivity under the effect of plant growth regulator in the conditions of insufficient moisture, Tricon Pub. House. 2(1): 196-217.

\section{How to cite this article:}

Pious Secondo, A.S. and Nanja Reddy, Y.A. 2018. Plant Growth Retardants Improve Sink Strength and Yield of Sunflower. Int.J.Curr.Microbiol.App.Sci. 7(10): 111-119. doi: https://doi.org/10.20546/ijcmas.2018.710.013 